\title{
The Effect of Coded and Uncoded Written Corrective Feedback on the Accuracy of Learners Writing in Pre-intermediate Level
}

\author{
Asghar Salimi \\ Department of English, University of Maragheh, Iran \\ E-mail: asgharsalimi356@gmail.com \\ Maryam Valizadeh \\ Department of English, University of Maragheh, Iran
}

Received: 23-09- 2014

Published: 01-05- 2015
Accepted: 15-12- 2014

doi:10.7575/aiac.ijalel.v.4n.3p.116
Advance Access Published: December 2014

URL: http://dx.doi.org/10.7575/aiac.ijalel.v.4n.3p.116

\begin{abstract}
To date, conflict exists in the literature on whether or not and how teachers should react to EFL learners' written grammar errors. Coded versus uncoded corrective feedback has been one of the rarely explored areas of investigation in SLA. To shed light on the factors that may explain such conflicting results, this study investigated the effect of coded and un-coded written corrective feedback with regard to possible improvements in the accuracy in writing of preintermediate EFL learners. It, further, sought whether such an effect would last in the long run. In the course of 14 weeks, learners' errors in 2 groups (i.e., coded and uncoded) were reacted. A paired-samples t-test was run to analyze the obtained data. Analysis of the written pieces in the immediate post-test and delayed post test revealed that coded corrective feedback, compared to the uncoded group, had a significantly more positive influence on learners' accuracy improvement both in the short and in the long run. The findings imply that teachers should weigh the learners' abilities and interlanguage, proficiency level, and type of error before applying different feedback types. Moreover, the implications are discussed in terms of effective guidelines for teaching writing in EFL contexts.
\end{abstract}

Keywords: written feedback, accuracy, EFL context

\section{Introduction}

In the process of learning, especially something new, there is always the possibility of making mistakes. In the history of language acquisition and learning, students and learners face so many difficulties in the process of learning. One of the most important difficulties is eliminating students' linguistic errors. When errors occur in the second language acquisition, we face another problem called error correction which always confuses teachers because they do not know whether this error should be corrected or not, and if so, when is the best time to correct it. Whether and how corrective feedback can help students to become good writers is of great interest for researchers (Chandler, 2003; Ferris, 2010).

Written corrective feedback (CF) is an important part of second language writing because it allows of providing teacher-to-student interaction in L2 writing class (Ferris, Pezone, Tade, \& Tinti, 1997). Many L2 writing teachers feel that written corrective feedback is influential in the improvement of their students' L2 writing accuracy (Brown, 2007; Hyland \& Hyland, 2006), although its effectiveness is under question (Truscott, 1996; Truscott \& Hsu, 2008). In addition, L2 writing students want and expect their teachers to correct written errors (Ferris \& Roberts, 2001; Lee, 2004) and prefer to receive written corrective feedback such as peer and oral feedback (Leki, 1991; Ferris, 1995). Students believe that a learning task is not complete without corrective feedback. Although there are various views on the impact of providing written corrective feedback on the improvement of L2 writing accuracy, both teachers and students feel the need for its use (Van Beuningen, 2010; Van Beuningen, De Jong, \& Kuiken, 2012).

L2 writers want to improve their grammatical accuracy and as a result, they expect to be corrected and value WCF from their teachers (Sheen, 2007; Truscott, 1996). However, previous studies of WCF have shown contradictory results. Some researchers have found evidence that WCF leads to lower error rates (Lalande, 1982); others are in favor of selective correction of specific error types (e.g., Ferris, 2006); still others have argued that error correction should be deleted because of its ineffectiveness in the long run (Krashen, 1984; Semke, 1984; Truscott, 1996). Truscott (2007) claimed a harmful effect of correction on learners' ability to write accurately and believed that due to CF, learners will avoid using certain language structures in subsequent writings.

Whether teachers should provide feedback on grammar in the writing errors of English language learners has caused considerable arguments in the field of second language acquisition (SLA). Some researchers (e.g., Kepner, 1991; Sheppard, 1992; Truscott, 2007) believe that grammar corrections have no effect on L2 writing accuracy development. According to Krashen (1982) and Truscott (2007), corrective feedback (CF) is seen as not only ineffective but also 
harmful. However, other researchers (Bitchener \& Knoch, 2008; Chandler, 2003; Ferris, 2002; Sheen, 2007) claim that CF promotes grammatical accuracy. According to Rahimpour, Salimi, and Farrokhi (2012), the high rate in accuracy can be attributed to the fact that the more frequent, repeated, and intensive the focus on form, the deeper the processing of target language feature takes place.

There are many different ways of supplying written CF on L2 learners' writing ranging from more explicit to more implicit (Van Beuningen, 2010). The two most prominent dichotomies are direct and indirect written CF. A range of studies have investigated whether certain types of WCF or their combinations are more influential than others. In these studies feedback is categorized as either direct (explicit) or indirect (implicit).

\section{Review of literature}

Written corrective feedback (CF) is an important part of second language writing because it allows of providing teacher-to-student interaction in L2 writing class (Ferris, Pezone, Tade, \& Tinti, 1997). Many L2 writing teachers feel that written corrective feedback is influential in the improvement of their students' L2 writing accuracy (Brown, 2007; Hyland \& Hyland, 2006), although its effectiveness is under question (Truscott, 1996; Truscott \& Hsu, 2008). In addition, L2 writing students want and expect their teachers to correct written errors (Ferris \& Roberts, 2001; Lee, 2004) and prefer to receive written corrective feedback such as peer and oral feedback (Leki, 1991; Ferris, 1995). Students believe that a learning task is not complete without corrective feedback. Although there are various views on the impact of providing written corrective feedback on the improvement of L2 writing accuracy, both teachers and students feel the need for its use (Van Beuningen, 2010; Van Beuningen, De Jong, \& Kuiken, 2012).

Written error correction plays an important role in improving L2 writing accuracy (Ferris \& Roberts, 2001; Lee, 2004; Brown, 2007), though debate over its effectiveness has increased in the past decade (Truscott, 1996; Chandler, 2003). Results of some studies (e.g., Krashen, 1985, 1999; Truscott \& Hsu, 2008; Semke, 1984) show that error correction is both ineffective and harmful in L2 writing classes. Therefore, Truscott (1996) argues that classroom time should not be spent on grammar instruction and correction and should be abandoned.

Lalande's (1982) study of 60 intermediate EFL learners indicated an advantage for indirect feedback over direct feedback but the difference was not statistically significant. Lee's (2008) survey also found that the use of a correction code is helpful if symbols are few in number and all understood by learners.

Sampson's (2012) study regarding the effects of un-coded correction which is writing the correct forms on each error and coded annotations which is writing symbols for learners in order to self-correct on EFL learners' written accuracy found that coded feedback seems to be more effective because of the increased cognitive engagement and social interaction it affords. Moreover, Erel and Bulut's (2007) study investigated the effects of direct and indirect coded error feedback on learners' accuracy in writing. According to the results of the study, learners receiving indirect coded feedback had fewer errors than the direct ones. It also seems logical that using a code engages learners in self-editing and cognitive error processing (Guénette, 2007).

There are other studies, however, that suggest that coded feedback may not lead to accuracy development. Ferris and Roberts (2001) found no significant differences the learners who corrected the underlined errors and those who selfcorrected errors marked with a code. Robb et al.'s (1986) study also showed no advantage for any of coded and uncoded feedback types. Similarly, in Semke's (1984) study, no difference between the two approaches was

However, three recent studies by Van Beuningan et al. (2012) and Bitchener and Knoch (2010b) indicated positive short-term effects for both direct and indirect feedback but direct error correction had a more significant long-term effect. Vyatkina's (2010) study was in favor of direct feedback which led to more successful revisions which showed that more implicit feedback types (coded) may be confusing for learners and lead to wrong guesses, which confirms previous research (e.g., Hedgcock \& Lefkowitz, 1996).

Some researchers (Bitchener, 2012; Polio, 2012) have discussed written error correction from the perspective of various approaches to SLA, for example generative theory, monitor theory (Krashen, 1985), skill acquisition theory (McLaughlin, 1987), processability theory (Pienemann, 1998, 2007; Pienemann \& Keßler, 2012), usage-based approaches (Ellis, 2007, 2012)., skill acquisition theory (DeKeyser, 2007), sociocultural theory (Lantolf, 2000, 2012), and the interaction approach (Hatch, 1978; Long, 1981, 1983) and what they might have to say about written error correction.

Whether and how corrective feedback can help students to become good writers is of great interest for researchers (Chandler, 2003; Ferris, 2010). Currently, the research focus is on the potential of written CF in helping learners' interlanguage development and most of the studies are mainly inspired by the proposals made by the Noticing Hypothesis by Schimdt (1994). An understating of this theory is felt necessary here.

\subsection{Schmidt's Noticing Hypothesis}

According to Schmidt (1994), noticing is effective in processing utterances and students can learn better if they notice the focused material in the linguistic data, that is, their attention should be directed to specific forms to help them recognize new linguistic features of the L2, therefore; written error correction can work as a facilitator that may promote learners' awareness. Subsequently, these noticing can help learners destabilize and restructure their interlanguage grammar (Long, 1996).

Moreover, written corrective feedback is expected to support the SLA process since continuous attention to forms are essential interlanguage development (Han, 2002). Ortega (2009) defines noticing as the process of absorbing new 
information even if it is remembered later on. In addition, Schmidt (1994) asserts that the more noticing happens, the more learners learn L2.

In sum, by providing error correction, students will pay attention to the new features of the L2 and be able to locate the gaps between their L2 and the L1 speaker's. Furthermore, error correction might help students to discover the limitations of their L2 communication abilities with their given L2 resources. Also, error correction could direct learners' attention not only towards error, but also towards new features of the target language.

A review of literature shows that there are two kinds of error feedback strategies used in EFL/ESL writing, that is, direct vs. indirect coded feedback. Although some studies compared these and other error correction strategies, there have been no longitudinal studies reported for the Iranian EFL context. Thus, this study is an attempt to identify the longitudinal effects of the two kinds of error feedback strategies, namely coded and un-coded in Iranian EFL context.

The researcher postulated the following research questions:

1. Is there a significant difference between coded and un-coded WCF in terms of their immediate effect on writing accuracy of EFL learners?

2. Is there a significant difference between coded and un-coded WCF (in terms of their delayed effect on writing accuracy of EFL learners?

Moreover, the researcher put forth the following null hypotheses:

1. There is no significant difference between coded and un-coded WCF in terms of their immediate effect on writing accuracy of EFL learners.

2. There is no significant difference between coded and un-coded WCF in terms of their delayed effect on writing accuracy of EFL learners.

\section{Method}

\subsection{Participants}

By means of Iran Language placement test, 4 intact classes including female pre-intermediate EFL learners were selected and randomly assigned into two groups receiving direct coded corrective feedback and indirect un-coded corrective feedback. The participants were within the age range of 14 to 17 having at least 2 years experience of learning English at secondary school and institutes and being involved in writing tasks (e.g., writing questions, summaries, compositions, etc.).

\subsection{Instruments}

In this study, the following instruments were used to pave the way for data collection procedures.

1. A highly valid and reliable proficiency test (i.e., $r=.90$ determined by the institute itself), institutionalized by Iran language institute, including questions on grammar and vocabulary accompanied with interview were utilized. It served the purpose of homogenizing the participants in terms of language proficiency at the outset of the study.

2. The researcher selected some topics covered in the students' books, namely, Pre-intermediate Student's Book for which the learners were required to write compositions.

\subsection{Procedure}

In the beginning of the study, all participants were assigned to write a composition on a topic. It served two purposes before the main treatment was initiated. First, to establish homogeneity among participants belonging to each proficiency group, the researcher scored all the written pieces in terms of accuracy. Second, to ensure that coding the errors in the pretest, all the ten sessions as well as in the immediate and delayed posttests enjoyed reliable procedures, two coders coded grammar errors (both in the direct coded and in the indirect un-coded cases) of $25 \%$ of the written pieces randomly selected from those collected in the pretest.

Before the treatment, the codes were taught to the participants who received indirect coded feedback. During the study, the participants were assigned into two groups, namely, indirect coded and uncoded corrective feedback. Then, both two groups were randomly divided into two classes writing collaboratively and individually. All 4 groups in each wrote one composition per week for at least 10 weeks on general topics covered in their students' books. They were asked to write compositions within a word limit of at least 150 in 40 minutes. Learners doing their first composition, that served the purpose of pre- and post-tests, were not allowed to have access to any resources and assistance.

The teacher underlined and corrected all the grammar errors in the written performances of the first treatment group, that is, direct coded CF. As for the second group, the same errors were underlined with codes on them for the students to self-correct.

Learners in the indirect coded group were given 25 minutes to individually check the errors underlined and coded by teacher and those in the paired groups did this in pairs as well; and those in the second group (i.e., direct uncoded group) were given 15 minutes to check and observe the errors corrected by the teacher in both groups (i.e., collaborative and individual. This procedure were followed for 10 weeks and at the end of the tenth composition, immediate post-test (i.e., the 10th composition) and delayed post-test, within a month time interval (i.e., 14th week) were conducted for all learners. 
Errors Focused on

\begin{tabular}{c|cc}
\hline Sings & Kind of Error & Example \\
\hline VT & Verb tense agreement & I go to the party yesterday. \\
\hline C & Capitalization & She was born in $\underline{\text { march. }}$. \\
\hline P & Punctuation & Did you study hard. \\
\hline Sp & Spelling & I love $\underline{\text { spageti. }}$ \\
\hline W.F & Word formation & I have a beauty house. \\
\hline$\wedge$ & Add something & She is $\ldots .$. teacher. \\
\hline$\varnothing$ & Delete (erase) & She is going $\underline{\text { to } \text { skiing. }}$ \\
\hline W.W & Wrong word & He $\underline{\text { meats } \text { me at school. }}$ \\
\hline S.V & Subject verb agreement & He play tennis. \\
\hline Pl/Sg & Plural/Singular mistake & I ate two loaf of bread.
\end{tabular}

\section{Results}

Table 2 shows descriptive statistics for the impact of coded feedback on learners' immediate and delayed writing accuracy.

Table 1. descriptive statistics for the impact of coded feedback on learners' immediate and delayed writing accuracy

\begin{tabular}{ccccc}
\hline & Mean & $\mathrm{N}$ & $\begin{array}{c}\text { Std. } \\
\text { Deviation }\end{array}$ & Std. Error Mean \\
\hline $\begin{array}{c}\text { Coded } \\
\text { (Pre-test) }\end{array}$ & 81.56 & 15 & 4.98 & 1.28 \\
$\begin{array}{c}\text { (Immediate } \\
\text { Post-test) }\end{array}$ & 90.24 & 15 & 2.29 & .69 \\
\cline { 2 - 5 }$($ Delayed \\
Post-test)
\end{tabular}

a. Corrective Feedback $=$ Coded

According to the mean scores, there was a significant difference between pre-test and immediate and delayed post-tests, that is, learners receiving coded feedback outperformed from pre-test to immediate and delayed post-tests (see Table 2).

Table 2. Paired Samples Test for Coded Feedback

\begin{tabular}{|c|c|c|c|c|c|c|c|c|c|}
\hline \multirow{4}{*}{$\mathrm{Pa}$} & & \multirow[t]{2}{*}{ Mea } & \multirow[t]{2}{*}{$\begin{array}{l}\text { Stc } \\
\text { Devia } \\
\text { tion }\end{array}$} & \multirow[t]{2}{*}{$\begin{array}{l}\text { Std. } \\
\text { Error } \\
\text { Mean }\end{array}$} & \multirow[t]{2}{*}{$t$} & \multirow[t]{2}{*}{$\mathrm{df}$} & \multirow[t]{2}{*}{$\begin{array}{c}\text { Sig } \\
\text { (2-tailed) }\end{array}$} & \multicolumn{2}{|c|}{$\begin{array}{l}95 \% \text { Confidence } \\
\text { Interval of the } \\
\text { Difference } \\
\end{array}$} \\
\hline & & & & & & & & Lower & Upper \\
\hline & $\begin{array}{c}\text { (Pretest) } \\
\text { (Immediate Post-test) }\end{array}$ & -9.63 & 4.61 & 1.19 & -8.08 & 14 & .00 & -12.18 & -7.07 \\
\hline & $\begin{array}{c}\text { (Pre-test) } \\
\text { (Delayed Post-test) }\end{array}$ & -8.67 & 5.95 & 1.53 & -5.64 & 14 & .00 & -11.97 & -5.38 \\
\hline \multicolumn{10}{|c|}{$\begin{array}{c}\text { (Immediate and Delayed post- } \\
\text { tests) }\end{array}$} \\
\hline & & .95 & 3.18 & .82 & 1.15 & 14 & .26 & -.81 & 2.71 \\
\hline
\end{tabular}

a. Corrective Feedback $=$ Coded 
A paired-samples t-test was conducted to evaluate the impact of coded feedback on learners' immediate writing accuracy. There was a statistically significant increase from pre-test $(M=81.56, S D=4.98)$ to immediate post-test $[M=90.24, S D=$ $2.29, t(14)=-8.08, p=.00]$. Also, there was a statistically significant increase from pre-test $(M=881.59, S D=4.98)$ to delayed post-test $[M=90.24, S D=2.293 .94, t(14)=-5.647 p=.00]$. Moreover, there was not a statistically significant increase from immediate post-test $(M=91.19, S D=2.00)$ to delayed post-test $[M=90.24, S D=.69, t(14)=1.15, p=.26]$.

Table 3 shows descriptive statistics for the impact of un-coded feedback on learners' immediate and delayed writing accuracy.

Table 3. descriptive statistics for the impact of un-coded feedback on learners' Immediate and delayed writing accuracy

\begin{tabular}{ccccc}
\hline & Mean & $\mathrm{N}$ & $\begin{array}{c}\text { Std. } \\
\text { Deviation }\end{array}$ & Std. Error Mean \\
\hline $\begin{array}{c}\text { (Pretest) } \\
\text { (Immediate }\end{array}$ & 82.52 & 15 & 6.46 & 1.80 \\
\cline { 2 - 5 } \begin{tabular}{c} 
Post-test) \\
\cline { 2 - 5 }
\end{tabular} & 82.01 & 15 & 5.53 & 1.43 \\
$\begin{array}{c}\text { (Delayed } \\
\text { Post-test) }\end{array}$ & 80.83 & 15 & 6.15 & 1.23 \\
\hline
\end{tabular}

a. Corrective Feedback $=$ Un-coded

According to the mean scores, there was not a significant difference between un-coded pre-test and immediate post-test and between pre-test and delayed post-test (see Table 4).

Table 4. Paired Samples Test for Un-coded Feedback

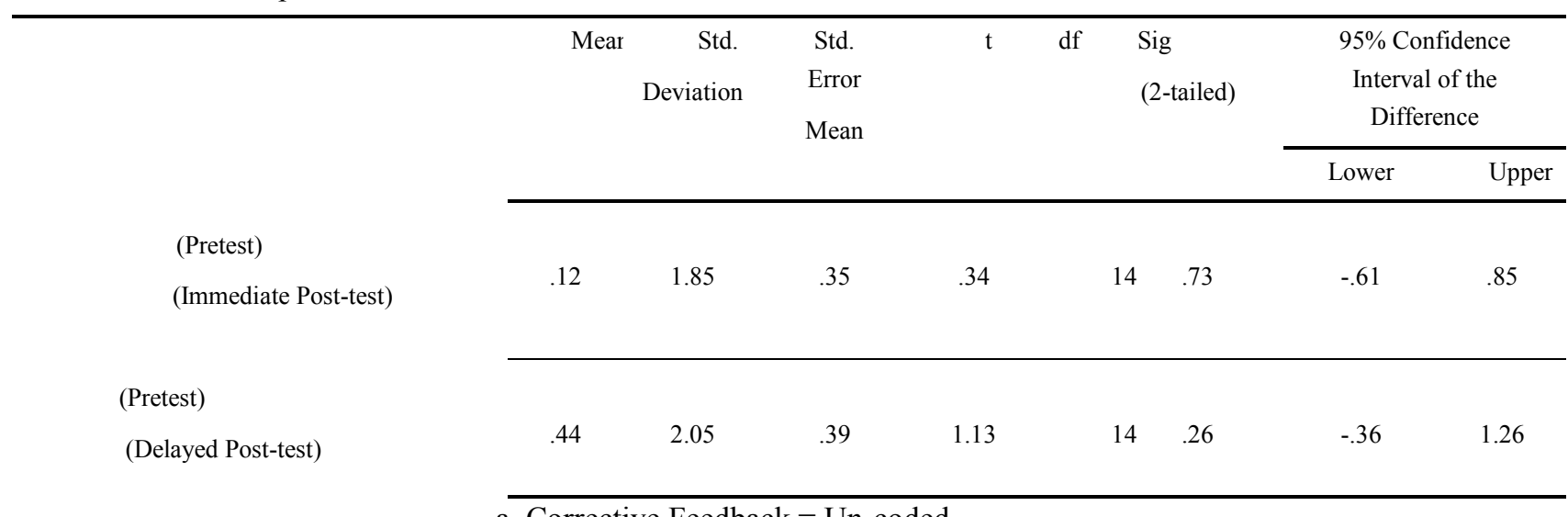

a. Corrective Feedback $=$ Un-coded

A paired-samples t-test was conducted to evaluate the impact of un-coded feedback on learners' immediate writing accuracy. There was not a statistically significant increase from pre-test $(M=82.52, S D=6.64)$ to immediate post-test $[M=82.01$, $S D=5.53, t(14)=.34, p=.73]$. Moreover, there was not a statistically significant increase from pre-test $(M=82.52$, $S D=6.64)$ to delayed post-test $[M=80.83, S D=6.15, t(14)=1.13, p=.26]$.

\section{Discussion and Conclusion}

This research aimed to investigate whether there is a difference in the effect of two written corrective feedback (i.e. codec and uncoded) on some selected target features in the short term and in the long run. After the 10-week experiment, the results showed that coded type of corrective feedback had a positive influence on students' accuracy in selecting grammatical structures and punctuation both in the short term and the long run. Both the long-term and shortterm mastery of the linguistic forms showed that the coded way of giving feedback seems to have a similar effect. This finding can well answer the research questions and indicates that teachers' decision on CF selection should depend on the acting time and the educational focus on the type of grammatical features.

Regarding the first research question, coded feedback group gradually decreased their number of errors during the semester they were included in the study. However, results did not reflect any significant difference across the three periods during the semester for the un-coded feedback group. The findings for the second research question revealed the same results as well.

This difference between indirect and direct error correction strategies finds support from the literature (Ferris, 2003; Fratzen, 1995; \& Chandler, 2003). More specifically, the difference between direct and coded indirect feedback 
strategies was supported by some researchers (Lalande, 1982; Lee, 2008; Sampson, 2012) who also compared these two strategies. In accordance with Lalande (1982) who showed that students who received indirect CF outperformed students in a direct CF group, the present study has given a crucial role to coded feedback type. He pointed out that learners will benefit considerably from indirect $\mathrm{CF}$ because they have to engage in a more profound form of language processing when they are self-correcting their errors. Moreover, it contributes more likely to long-term learning since it induces deeper internal processing. This study stressed on the durable effects of indirect corrective feedback that contradict the fact that direct CF was more effective than indirect feedback (Van Beuningen et al., 2008a; Sheen et al., 2009).

Results of the study corroborate those of Ferris's study (2006) who found that indirect corrective feedback was more beneficial to accuracy development. Learners benefit more from indirect CF because they have to engage in a more profound form of language processing as they are self-editing their output (Ferris, 1995). Moreover, learners had errors in all the selected grammatical features in the study; however, the number of Verb tense, Capitalization, Punctuation and Spelling errors was higher. The results showed that coded error feedback had a great impact in error reduction both in short term and long run which are somehow in accordance with results obtained from Sampson's (2012) study.

Based on the findings mentioned above, some implications could be drawn. Certain error types appear to be more persistent and more likely to be affected by feedback types such as Verb tense, Capitalization, Punctuation and Spelling errors, etc. Moreover, we should select the type of feedback depending on learners' interlanguage since comprehensive feedback may demotivate and discourage learners from taking risks and trying more sophisticated language forms.

Some important limitations of our study are in order here. First, the sample size of the data used in our study was somehow small. A replication with a larger sample size, therefore, would be needed to verify the findings of the current study. As most of the findings from other cultures or contexts cannot always be generalized, the findings of this research cannot also be generalized beyond its pre-defined context.

\section{Reference}

Bitchener, J. (2012). A reflection on 'the language learning potential' of written CF. Journal of Second Language Writing, 21, 348-363

Bitchener, J., \& Knoch, U. (2008). The value of written corrective feedback for migrant and international students. Language Teaching Research, 12, 409-431.

Bitchener, J., \& Knoch, U. (2010b). Raising the linguistic accuracy level of advanced L2 writers with written corrective feedback. Journal of Second Language Writing, 19, 207-217.

Bitchener, J., Young, S., \& Cameron, D. (2005). The effect of different types of corrective feedback on ESL student writing. Journal of Second Language Writing, 14, 191-205.

DeKeyser, R. (Ed.). (2007). Practicing in a second language: Perspectives from applied linguistics and cognitive psychology. Cambridge: Cambridge University Press.

Ellis, R., Basturkmen, H., \& Loewen, S. (2001). Preemptive focus on form in the ESL classroom. TESOL Quarterly, 35, 407-432.

Ellis, N. (2007). The associative-cognitive CREED. In B. VanPatten \& J. Williams (Eds.), Theories in second language acquisition: An introduction (pp. 77-96). Mahwah, NJ: Erlbaum.

Ellis, N. (2012). Frequency-based accounts of second language acquisition. In S. Gass \& A. Mackey (Eds.), The Routledge handbook of second language acquisition (pp. 193-210). New York: Routledge.

Erel, S. \& Bulut, D. (2007). Error treatment in L2 writing: A comparative study of direct and indirect coded feedback in Turkish context. Social Sciences Institute, 1, 397-415.

Ferris, D. R. (2003). Response to student writing: Implications for second language students. Mahwah, NJ: Lawrence Erlbaum Associates.

Ferris, D. R. (2006). Does error feedback help student writers? New evidence on the shorthand long-term effects of written error correction. In K. Hyland \& F. Hyland (Eds.), Feedback in second language writing: Contexts and issues (pp. 81-104). Cambridge, UK: Cambridge University Press.

Ferris, D. R., \& Roberts, B. (2001). Error feedback in L2 writing classes: How explicit does it need to be? Journal of Second Language Writing, 10(3), 161-184.

Guenette, D. (2007). Is feedback pedagogically correct? Research design issues in studies of feedback on writing. Journal of Second Language Writing, 16, 40-53.

Hatch, E. (1978a). Acquisition of syntax in a second language. In J. Richards (Ed.), Understanding second and foreign language learning: Issues and approaches (pp. 34-70). Rowley, MA: Newbury House.

Hedgcock, J., \& Lefkowitz, N. (1996). Some input on input: Two analyses of student response to expert feedback in L2 writing. Modern Language Journal, 80, 287-308.

Heift, T. (2010). Prompting in CALL: A longitudinal study of learner uptake. Modern Language Journal, 94, 198-216. 
Hyland, K., \& Hyland, F. (2006). Contexts and issues in feedback on L2 writing: An introduction. In K. Hyland \& F. Hyland (Eds.), Feedback in second language writing: Contexts and issues (pp. 1-19). Cambridge, UK: Cambridge University Press.

Krashen, S. D. (1984). Writing: Research, theory, and application. Oxford: Pergamon Press.

Krashen, S. D. (1985). The input hypothesis: Issues and implications. London: Longman.

Lalande, J. F. (1982). Reducing composition errors: An experiment. Modern Language Journal, 66, 140-149.

Lantolf, J. (Ed.). (2000). Sociocultural theory and second language learning. Oxford: Oxford University Press.

Lantolf, J. (2012). Sociocultural theory: A dialectical approach to L2 research. In S. Gass \& Mackey (Eds.), The Routledge handbook of second language acquisition (pp. 57-72). New York: Routledge.

Lee, I. (2008). Understanding teachers' written feedback practices in Hong Kong secondary classrooms. Journal of Second Language Writing, 17, 69-85.

Long, M. H. (1981). Input, interaction, and second language acquisition. In Winitz, H. (Ed.). Native language and foreign language acquisition (pp.259-278). Annals of the New York Academy of Science.

Long, M. H. (1983). Linguistic and conversational adjustments to non-native speakers. Studies in Second Language Acquisition, 5, 177-193.

McLaughlin, B. (1987). Theories of second language learning. London: Edward Arnold.

Pienemann, M. (1998). Language processing and second language development: Processability theory. Amsterdam: Benjamins.

Pienemann, M. (2007). Processability theory. In B. VanPatten \& J. Williams (Eds.), Theories in second language acquisition: An introduction (pp. 137-154). Mahwah, NJ: Erlbaum.

Pienemann, M., \& Keßler, J. (2012). Processability theory. In S. Gass \& A. Mackey (Eds.), The Routledge handbook of second language acquisition (pp. 228-247). New York: Routledge.

Polio, C., Fleck, N., \& Leder, N. (1998). "If only I had more time": ESL learners' changes in linguistic accuracy on essay revisions. Journal of Second Language Writing, 7, 43-68.

Polio, C. (2012). The relevance of second language acquisition theory to written error correction debate. Journal of Second Language Writing, 21, 375-389.

Rahimpour, M., Salimi, A., \& Farrokhi, F. (2012). The impact of extensive and intensive focus on form strategies on EFL learners' oral accuracy. International Journal of Applied Linguistics \& English Literature, 1(6), 37-43.

Robb, T., Ross, S., \& Shortreed, I. (1986). Salience of feedback on error and its effect on EFL writing quality. TESOL Quarterly, 20, 83-93.

Sampson, A. (2012). Coded and uncoded error feedback: Effects on error frequencies in adult Colombian EFL learners' writing. System, 40, 494-504.

Semke, H. (1984). The effects of the red pen. Foreign Language Annals, 17, 195-202.

Sheen, Y. (2007). The effect of focused written corrective feedback and language aptitude on ESL learners' acquisition of articles. TESOL Quarterly, 41, 255-283.

Sheen, Y., Wright, D., \& Moldawa, A. (2009). Differential effects of focused and unfocused written correction on the accurate use of grammatical forms by adult ESL learners. System, 37(4), 556-569.

Truscott, J. (1996). The case against grammar correction in L2 writing classes. Language Learning, 46, 327-369.

Truscott, J. (2007). The effect of error correction on learners' ability to write accurately. Journal of Second Language Writing, 16, 255-272.

Van Beuningen, C., De Jong, N., \&Kuiken, F. (2008a). The effect of direct and indirect corrective feedback on L2 learners' written accuracy.ITL International Journal of Applied Linguistics, 156, 279-296.

Van Beuningan, C., de Jong, N. H., \& Kuiken, F. (2012). Evidence on the effectiveness of comprehensive error correction in Dutch multilingual classroom. Language Learning, 62, 1-41.

Vyatkina, N (2010). The Effectiveness of Written Corrective Feedback in Teaching Beginning German. Foreign Language Annals, 43, 671-689. 